\title{
THE ATRACTTIVENESS OF REAL ESTATE INVESTMENT IN POLISH CONDITIONS
}

\author{
Rafał Wolski, PhD. \\ Department of Economics of Industry and Capital Markets \\ Universiy of Lodz \\ emai: rwolski@uni.lodz.pl
}

Magdalena Załęczna, PhD.

Department of Investment and Real Estate

University of Lodz

email:mzaleczna@uni.lodz.pl

\begin{abstract}
Traditionally, it is believed that real estate can be an important component of an investment portfolio as it reduces risk due to the diversification potential coming from its low/negative correlation with stocks and bonds. However, contemporary development in the form of the invention and introduction of more sophisticated financial instruments is blurring the boundaries between the existing asset classes. The appearance of these new forms of investments is the result of competition for global capital inflows. Investors concentrate on those forms of investments that are attractive in terms of the variety of offered instruments and the results achieved by them. The aim of the article is to evaluate the variety of instruments enabling investments on the Polish property market and their competitiveness in relation to classical forms of investment.
\end{abstract}

Keywords: real estate, investment, portfolio, Poland.

JEL Classification: G11, R30.

Citation: Załęczna M, Wolski R, (2012), "The potential of real estate investment in Polish conditions", Real Estate Management and Valuation, vol. 21, no. 3, pp. 62-70.

DOI: 10.2478/remav-2013-0027.

\section{Introduction}

Traditionally, financial instruments, such as bonds and stocks, are identified as the main component of an investment portfolio and diversification can be increased, among others, by the addition of real estate (BROWN, MATYSIAK 2000). However, real estate means specific problems. It has particular features, such as: a permanent location, uniqueness, a strong interaction with the local environment, and the fact that it requires a high amount of capital and, what is associated with this drawback, is not easy to sell quickly without lowering the price (in relation to the market value). These features make it difficult to evaluate whether the inclusion of real estate in an investment portfolio is justified in comparison to other types of assets and the size of the potential engagement without possessing the knowledge of an investor's priorities. Although the evaluation of the potential of investment in financial assets is based on ever more elaborate methods rooted in the Modern Portfolio Theory, their direct application to real estate is subject of criticism ${ }^{1}$.

The capital market is constantly developing as a result of globalization, technological and cultural

\footnotetext{
${ }^{1}$ E.g., the analytical difficulty of comparing what are actually non-comparable assets is stressed by, inter alia, the title of one of the scientific articles on this subject matter: "Stock are from Mars and a real estate is from Venus" (Pai, Geltner 2007).
} 
changes. There are more and more sophisticated instruments, which often combine the features of different types of investments. Widely and easily accessible information gives greater transparency of the market.

In some countries, real estate markets try to keep up with the changes; they have become more transparent and in doing so, gained a wider acceptance from institutional investors (CLAYTON ET AL. 2007). Existing data bases create the possibility to compare real estate and other directions of investment, and also evaluate an individual project having information about the profitability of similar projects. A greater maturity of real estate markets may be observed primarily in the USA, Western Europe and some Asian countries (IPD, NCREIF indices). It stems primarily from the development of real estate investment funds (in the legal form of Real Estate Investment Trusts) and securitization. Obligations arising from participation in the public market enabled a better dissemination of information and more credible assessment of the attractiveness of modern types of investments. The public market also means a greater ability to withdraw funds by investors, so it creates higher flexibility. The development of real estate markets contributed to engaging a very important source of funding in the form of global capital (FIORILLA, KAPAS, LIANG 2012). However, an accurate description of the influence of various types of real estate investments on the degree of portfolio diversification is not simple due to great discrepancies concerning the research period and the range of the studied market (BRUEGGEMAN, FISHER 1997; EICHHOLTZ 1997; CORGEL ET AL 1998; LEE and STEVENSON 2005). As research analyses show (HEANEY and SRIANANTHAKUMAR 2012; GEORGIEV, GUPTA, KUNKEL 2004), direct and indirect investments on the property market have different degrees of correlation with the stock market and are not always desired diversifiers.

The authors formulate a research question concerning the attractiveness of the Polish property market. An attractive market is understood as a market having: a variety of offers (types) and competitiveness of investment results in comparison with other directions of investment. The answer to the above question has been sought both in literature and in conducted analyses.

\section{The attractiveness of real estate markets}

Global capital flows are currently a process that is observed worldwide where institutional investors, who manage funds entrusted to them, play a particular role. They must focus on seeking profitable and relatively safe investments. The belief that real estate makes for attractive investments is reflected by the fact that these assets have been incorporated into investment portfolios. However, in percentage terms, their share is not big; in the 90 's it was about $5 \%$, in the next decade, about $8 \%$, and it is anticipated to remain similar in the future (CLAYTON ET AL. 2007). However, in terms of the value of capital looking for best investment types, this percentage constitutes very significant inflow of funds, necessary for the development of real estate market. The multidimensional evaluation of real estate investments depends on the investor's perception of profits and security, as well as the prestige. More mature markets offer more investment opportunities, they are able to adapt to changes in a flexible way (ZAŁĘCZNA 2010). Less mature markets may, however, offer higher yields, though this is connected with a higher risk. This risk can have various sources one of which is the alienation of legal and economic conditions for foreign investors.

Due to the considerable dependence on specific legal regulations, it is very difficult to holistically evaluate the level of maturity of individual national real estate markets that compete with others. Such an attempt has already been made and a ranking of the attractiveness of numerous countries has been established, from the point of view of institutional investments on the real estate market (LIESER, GROH 2011).

The criteria of attractiveness were based not only on the state of development of the real estate market in a given country, but also on the level of economic development and functioning of the legal environment - see table 1 . The above-mentioned criteria were used to establish the ranking, which encompassed 66 national real estate markets with Poland ranked 26th (LIESER, GROH 2011). Leaders in the ranking were the United States, the United Kingdom, Hong Kong, Australia and Canada, thus Anglo-Saxon countries. The best countries in continental Europe were Germany and the Netherlands, positioned at 7 and 9 respectively.

The Polish score is not especially satisfactory in terms of the desired inflow of international investment capital. The evaluation which placed Poland in the 26th position was comprised of individual scores: 76.9 points in the category of economic development, 44.5 points in the category of 
real estate investment opportunities, 50.2 in terms of the level of development of the capital market, 70.1 points in the category of protection of investors and legal framework, 88.3 points for administrative and legal barriers and finally, 77.5 points in the sphere of the socio-political environment. The maximum score in each category was 100 points.

Table 1

Criteria of real estate investment attractiveness

\begin{tabular}{|c|c|c|}
\hline Economic activity & Real estate investment opportunities & $\begin{array}{l}\text { Depth and sophistication of } \\
\text { Capital Market }\end{array}$ \\
\hline Size of economy [+] & Institutional property estimation $[+]$ & Stock market liquidity [+] \\
\hline GDP per capita [+] & Degree of urbanization $[+]$ & IPO market activity [+] \\
\hline GDP growth [+] & Urban population [+] & M\&A market activity [+] \\
\hline Working force [+] & Quality of infrastructure [+] & Debt \& credit market [+] \\
\hline Inflation [-] & Development of service sector [+] & Access to private capital [+] \\
\hline Innovation \& Technology [+] & & REIT market [+] \\
\hline $\begin{array}{l}\text { Investor protection and legal } \\
\text { framework }\end{array}$ & $\begin{array}{l}\text { Administrative burdens and regulatory } \\
\text { limitations }\end{array}$ & $\begin{array}{l}\text { Socio-cultural and political } \\
\text { environment }\end{array}$ \\
\hline Investor protection $[+]$ & Taxation \& capital gains taxation [-] & Human development [+] \\
\hline Security of property rights $[+]$ & Ease of getting a construction permit [+] & Crime [-] \\
\hline Quality of legal enforcement [+] & Ease of registering property [+] & Bribing \& corruption [-] \\
\hline Regulatory quality [+] & Ease of starting a business [+] & Political system stability [+] \\
\hline & Ease of closing a business $[+]$ & \\
\hline
\end{tabular}

Signs [+] or [-] indicate the impact on real estate investment activity. Source: LIESER, GROH (2011, p. 195).

It is visible at first glance what the source of such a distant place in the ranking is - a limited choice of real estate investment opportunities, including modern instruments of the real estate market, as part of the capital market. In Poland, there is no real estate investment fund like the REIT. Existing real estate funds can act directly on the real estate market only in the form of closed-end funds, and mortgage backed securities are rarely issued. Modern forms of real estate investments exist, but their variety is low. IPD indices created for many countries and regions present the Polish real estate market together with five others as the Central Europe Index. The data base shows modest development, as the index is based on only 529 commercial properties worth 14.6 billion euros.

The summary of this data allows some considerations concerning investment directions in Poland to be undertaken. In the light of the low score of investment attractiveness on the Polish real estate market, the authors decided to conduct their own analysis. They concentrated on the results of investments in direct and indirect instruments on the Polish real estate market as components of an investment portfolio.

\section{The attractiveness of a property as a component of an investment portfolio in Polish conditions}

Similarly to HARTZELl (HARTZELl, HEKMAN, Miles 1986), the authors of the present article decided to analyze statistics referring to Polish capital market instruments with particular emphasis placed on the real estate market (the real estate market is considered to be a part of the capital market). The formulated research hypothesis - investments in real estate may become efficient diversifiers of a portfolio 
based on classic stock investments, thanks to which they become an attractive alternative for investors - was verified through the analysis of such indices as: the measure of sensitivity and selected measures of dispersion. It was assumed that diversity in the value of these indices allows the portfolio properties to change effectively. According to the classic portfolio theory, a correlation coefficient between the assets that is different from one unity is a desired phenomenon. Additionally, the observations were verified by creating an optimal portfolio, from the point of view of overall risk and the investors' aversion to risk.

The most serious problem which the authors encountered was the lack or relatively low value of data concerning the Polish real estate market. This is one of the reasons why the Polish real estate market received such a low attractiveness evaluation. From the investor's point of view, there is no transparency that would allow real estate to be evaluated in relation to other asset classes and individual real estate investment projects. Information about direct investments are not easily accessible, there are no indices relating to either commercial or residential markets. On the Polish real estate market, there is one hedonic index published by the NBP, however, the data it contains has been collected randomly since 2006 and NBP itself warns against using it ${ }^{2}$. The authors decided not to rely on fragmentary data from the commercial real estate market and limited themselves to the database of transaction prices on the secondary residential market (PKO BP SA database). They are aware of the impact of such a constraint on the completeness of the research, nevertheless, the size of the database and current recognition of residential real estate as an investment good were considered sufficient reasons for taking this course of action.

Transaction prices from the five biggest cities in Poland were included in the research. These prices are the median of a given city's prices for the end of a given quarter of a year. The study took into account data from the fourth quarter of 2005 to the third quarter of 2012. Residential real estate data was matched with its capital market counterpart. The authors undertook an attempt at analyzing indirect investments available on the Polish market, provided the assets were recorded throughout the entire considered period. This set of assets was connected with the attempt to bring the characteristics of the undertaken investments as close to each other as possible. The instruments quoted on the Warsaw Stock Exchange (GPW) were in the form of: investment certificates of two close-end real estate investment funds run by Arka and BPH, WIG-Budownictwo, WIG 20, ten-year DS 1013 government bonds and securities of three companies in the development sector: Echo, GTC, Polnord. The analysis also included two-year bonds of subsequent emissions assuming a coupon rate of return for the given quarter.

The WIG Index and a quarterly average of nine-year DS 1021 government bonds yield (risk-free rate) were assumed as the benchmark. While collecting stock market data, certain problems were encountered. The Polish real estate market seems to be a shallow one, particularly in relation to investments listed on the capital market. For instance, the analysis did not include any mortgage bonds, although such bonds are issued by BRE Bank Hipoteczny and PEKAO Bank Hipoteczny. However, the mortgage bonds that were placed on the market generate hardly any liquidity. Similar problems were encountered on the market of debt instruments treated as an alternative for investments in real estate. This problem concerns particularly the bonds of smaller bond issuers municipalities or enterprises. Investors are particularly interested in State Treasury bonds. Corporation bonds were not included in the analysis as those recorded in the studied period, EIB0617 and EIB0526, did not even have a single transaction. The lack of liquidity is a major reason why investors may favor certain assets, even if others seem to be much safer. A range of statistical measures were applied in the analysis in an attempt to discover the similarities, differences and dependencies between various types of investments. The analysis was carried out calculating selected measures. Based on the analysis of these measures, the authors could draw conclusions that led to the verification of their hypothesis.

\section{Results}

The results of the study are presented in the form of tables. Statistics have been presented in Table 2, beginning with the average quarterly rate of return. Although Polnord achieved the maximum rate of

2 "NBP residential real estate database BaRN is being created thanks to voluntary data transfer by the real estate brokers and developers and with the engagement of regional NBP branches", NBP internet service, http://nbp.pl/publikacje/rynek_nieruchomosci/ceny_mieszkan.xls, as of 15-03-2013. 
return, the analysis of the rate of return for residential investments brings about other interesting conclusions. Direct investments appear attractive reaching an average monthly rate of return at a level of $2.8-3.5 \%$.

The analysis of standard deviation made it possible to determine which investments were characterized by the greatest volatility and thus, investment risk. The rate of return of companies from the developer sector turned out to be most dispersed (64.1\% for Polnord). They were followed by stock market indices with a high volatility. This result remains in accordance with intuition. Stock investments change their values very quickly, sometimes many times in one minute. The activity sector of the issuer is irrelevant here. The lowest levels of risk, as was to be expected, were recorded for government bonds. Funds that make investments on the real estate market and residential investment obtained very similar levels of standard deviation, higher than that of government bonds, but lower than indices. That means that the investor does not have to invest directly on the property market to obtain assets of certain parameters. A more detailed analysis, however, is disillusioning. Clearly, funds cannot work out the kind of profit that a direct investment can. This is clearly reflected in the level of the coefficient of variation. The coefficient of variation may be interpreted as the "price of risk". The lower it is, the more willing the investor should be to undertake such an investment. The border level of the coefficient is zero. Coefficients of variation below zero mean that the investment noted a negative rate of return, which excludes it from an investor who is characterized by an aversion to risk, thus the average, typical investor.

Analysis of the beta coefficient demonstrates the attractiveness of direct investments on the secondary residential market. This coefficient, described as a vulnerability measure, shows how a given element of assets reacts to a change of the market index rate of return . In this analysis, WIG, the widest Polish index, was assumed as the benchmark. Beta coefficients oscillating between the values of -1 and 1 (the closer to zero, the better) mean that a given investment is independent of the cycle on the capital market. Beta coefficients of -1 and 1 as well as those below and above those numbers signify a high volatility of investment prices. Positive beta coefficients indicate following the market movements, whilst negative ones mean going against it.

Summary statistics of quarterly returns for the period of 2005Q4 - 2012Q3

Table 2

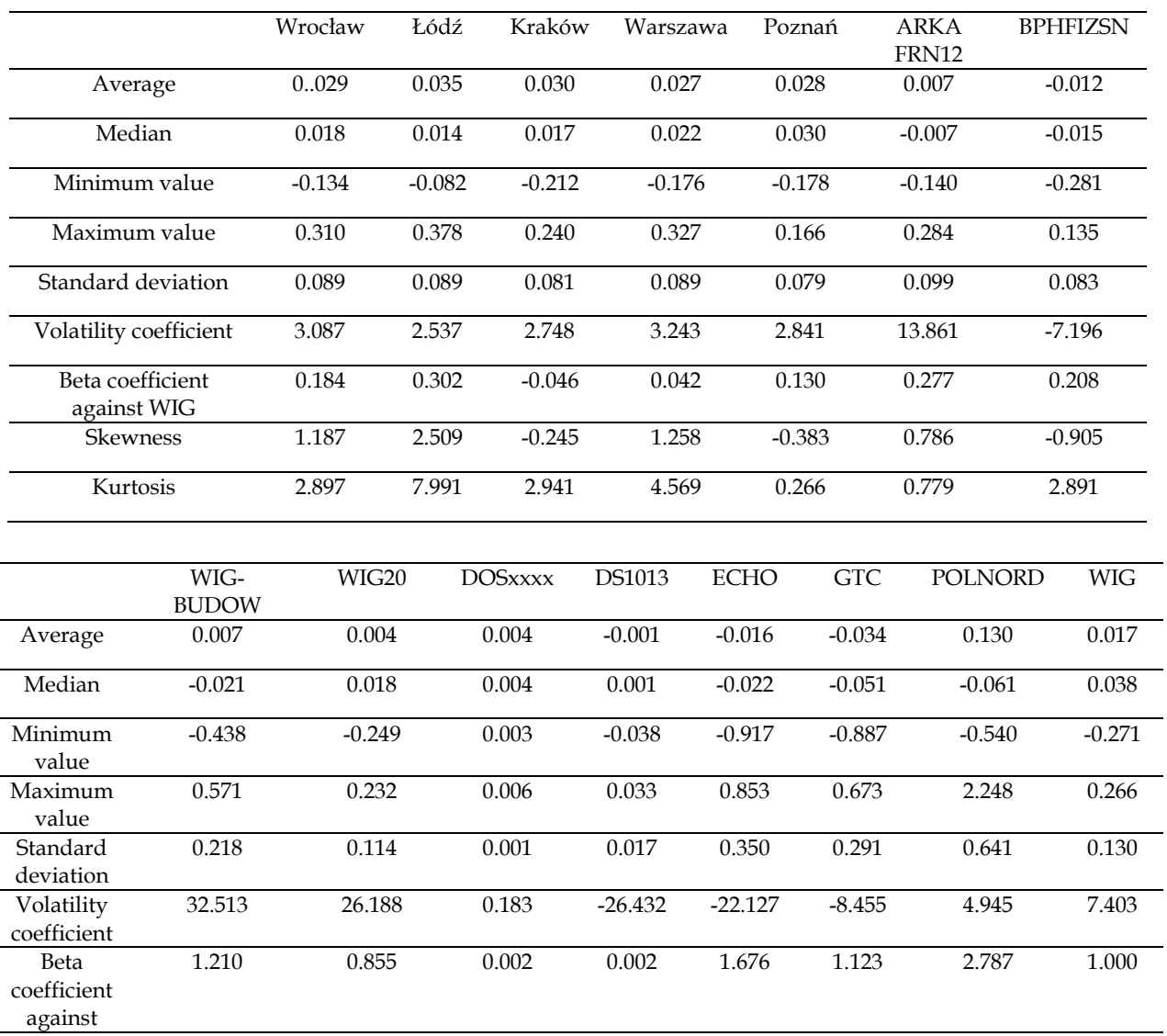




\begin{tabular}{ccccccccc}
\hline WIG & & & & & & & & \\
\hline Skewness & 0.478 & -0.389 & 0.475 & -0.218 & -0.277 & -0.178 & 2.337 & -0.248 \\
\hline Kurtosis & 0.733 & 0.086 & -0.860 & -0.024 & 1.730 & 2.582 & 5.714 & -0.249 \\
\hline
\end{tabular}

Source: own work.

Table 3

Correlations between the rates of return on different assets - property, shares, investment certificates and bonds

\begin{tabular}{|c|c|c|c|c|c|c|c|c|}
\hline Correlations & Wrocław & Łódz & Kraków & Warszawa & Poznań & \multicolumn{2}{|c|}{ ARKAFRN12 } & BPHFIZSN \\
\hline Wrocław & 1.000 & 0.249 & $0.460^{*}$ & $0.381^{*}$ & 0.200 & \multicolumn{2}{|l|}{-0.029} & -0.010 \\
\hline Łódź & & 1.000 & 0.332 & 0.252 & $0.418^{*}$ & \multicolumn{2}{|l|}{$0.463^{*}$} & 0.263 \\
\hline Kraków & & & 1.000 & 0.168 & $0.500^{* *}$ & \multicolumn{2}{|l|}{0.168} & -0.005 \\
\hline Warszawa & & & & 1.000 & $0.508^{* *}$ & \multicolumn{2}{|l|}{0.063} & $-0.516^{* \star}$ \\
\hline Poznań & & & & & 1.000 & \multicolumn{2}{|l|}{0.237} & -0.217 \\
\hline ARKAFRN12 & & & & & & \multicolumn{2}{|l|}{1.000} & $0.453^{*}$ \\
\hline BPHFIZSN & & & & & & & & 1.000 \\
\hline \multicolumn{9}{|l|}{ WIG_BUDOW } \\
\hline \multicolumn{9}{|l|}{ WIG20 } \\
\hline \multicolumn{9}{|l|}{ DOSxxxx } \\
\hline \multicolumn{9}{|l|}{ DS1013 } \\
\hline \multicolumn{9}{|l|}{$\mathrm{ECHO}$} \\
\hline \multicolumn{9}{|l|}{ GTC } \\
\hline \multicolumn{9}{|l|}{ POLNORD } \\
\hline \multicolumn{9}{|l|}{ WIG } \\
\hline Correlations & WIG_BUDOW & WIG20 & DOSxxxx & DS1013 & ECHO & GTC & POLNORD & WIG \\
\hline Wrocław & $0.425^{*}$ & 0.141 & 0.368 & -0.060 & -0.160 & -0.283 & 0.254 & 0.267 \\
\hline Łódź & $0.567^{* *}$ & $0.377^{*}$ & 0.365 & 0.006 & 0.223 & 0.263 & $0.818^{* *}$ & $0.442^{*}$ \\
\hline Kraków & 0.289 & -0.189 & $0.385^{*}$ & -0.145 & -0.216 & -0.318 & 0.262 & -0.073 \\
\hline Warszawa & 0.139 & 0.040 & 0.039 & 0.348 & $\begin{array}{c}-0.070 \\
\end{array}$ & -0.195 & 0.104 & 0.061 \\
\hline Poznań & $0.476^{*}$ & 0.175 & 0.192 & 0.011 & $\begin{array}{c}-0.067 \\
\end{array}$ & 0.018 & 0.290 & 0.212 \\
\hline ARKAFRN12 & $0.502^{* *}$ & 0.357 & 0.234 & 0.116 & 0.307 & 0.324 & $0.639^{* *}$ & 0.363 \\
\hline BPHFIZSN & 0.325 & 0.312 & 0.186 & -0.279 & 0.217 & $0.380^{*}$ & $0.444^{*}$ & 0.323 \\
\hline WIG_BUDOW & 1.000 & $0.642^{* *}$ & $0.454^{*}$ & 0.046 & $0.511^{* *}$ & $0.531^{* *}$ & $0.746^{* *}$ & $0.718^{* *}$ \\
\hline WIG20 & & 1.000 & 0.335 & 0.031 & $0.613^{* *}$ & $0.537^{* *}$ & $0.502^{* *}$ & $0.972^{* *}$ \\
\hline DOSxxxx & & & 1.000 & -0.067 & 0.155 & 0.015 & 0.335 & 0.353 \\
\hline$\overline{D S 1013}$ & & & & 1.000 & 0.112 & 0.010 & 0.133 & 0.016 \\
\hline ECHO & & & & & 1.000 & $0.715^{* *}$ & $0.493^{* *}$ & $0.620^{* *}$ \\
\hline GTC & & & & & & 1.000 & $0.514^{* *}$ & $0.500^{* *}$ \\
\hline POLNORD & & & & & & & 1.000 & $0.563^{* *}$ \\
\hline WIG & & & & & & & & 1,000 \\
\hline
\end{tabular}

* Correlation is significant at a level of 0.05 (two-sided) ${ }^{* *}$ Correlation is significant at 0.01 (two-sided),

Source: own work.

From the point of view of the beta coefficient, investments on the residential market seem 
attractive ${ }^{3}$. In the case of government bonds, beta coefficients point to values close to zero, and these bonds are generally considered to be a safe direction of investments.

The analysis of descriptive measures raises the suspicion that none of the distributions is a normal one. The closest to normal is the distribution of the rate of return of direct residential investments in Poznań. However, these statistics are affected by the problem of a low number of observations. Nevertheless, assuming the results are correct, a conclusion that all assets are rather similar in terms of distribution can be drawn.

The Pearson coefficient analysis presented in Table 3, leads to the conclusion that the analyzed assets may contribute to the diversification of a portfolio. In their vast majority, direct investments on the residential market and in closed-end real estate investment funds have correlation coefficients below 0.5 in relation to other investments. A similar situation takes place in the case of government bonds. Here, the level of correlation is even lower. These observations are confirmed by values of the beta coefficient.

The analysis of portfolio optimization presented in Table 4, from the point of view of overall risk and assuming a risk-free rate at the level of $4.944 \%$ annually and no short sale, proved that real estate may diversify the portfolio, although the beneficial combination of risk and rate of return results in eliminating all other investment instruments from it (including government bonds which are very secure but have very low profitability). One must not forget, however, about the constraints of direct investments in real estate which have not been mentioned here. They result from the high capital consumption and low liquidity that may exclude the instrument from the area of investors' interests (Lin, Vandell 2005; Bond, Hwang, Richards 2006). In Polish conditions, there is no data that would enable the influence of these extremely significant factors to be included in the study.

The authors carried out portfolio optimization with no direct residential investments; however, the classic Markovitz method gave no results that would be of interest from the point of view of the stated hypothesis and results, allocating all funds in stocks. More importantly, however, classic portfolio optimization did not help to find answers to the question as to how much investments on the real estate market may interest investors seeking alternatives to stocks. These results are not contradictory to the hitherto observations, they are merely an indicator that portfolio analysis should be approached slightly more creatively.

Correlation coefficients analysis in particular, showed how much diversification potential there is in real estate. What draws attention, is the great similarity in the results for development companies and enterprises from other sectors - represented in the sample by the WIG 20 index. Thus, "real estate" enterprises will not significantly influence the change of character of a portfolio. However, closed-end real estate investment funds already existing on the Polish real estate market present a great similarity to direct residential investments. This could be an interesting investment direction, although investors should be careful, considering the coefficients of variation and thus, the average rate of return.

Table 4

An example of an optimal portfolio

\begin{tabular}{|c|c|c|c|c|c|}
\hline \multicolumn{6}{|c|}{ The shares in the portfolio optimized due to the overall risk } \\
\hline Wrocław & Łódź & Kraków & Warszawa & Poznań & Other assets \\
\hline 0.147 & 0.390 & 0.238 & 0.154 & 0.072 & 0.000 \\
\hline \multicolumn{6}{|c|}{ Basic statistics of the portfolio } \\
\hline \multicolumn{3}{|c|}{ Standard deviation } & \multicolumn{2}{|c|}{0.060} & \\
\hline \multicolumn{3}{|c|}{ Rate of return } & \multicolumn{2}{|c|}{0.031} & \\
\hline \multicolumn{3}{|c|}{ Volatility coefficient } & \multicolumn{2}{|c|}{1.940} & \\
\hline \multicolumn{3}{|l|}{ Beta } & \multicolumn{2}{|c|}{0.150} & \\
\hline \multicolumn{3}{|c|}{ Sharpe ratio } & \multicolumn{2}{|c|}{0.311} & \\
\hline
\end{tabular}

Source: own work.

\footnotetext{
${ }^{3}$ Although it is necessary to add that there are numerous doubts if this coefficient may be calculated for assests
} that are not included in the benchmark. 
Summarizing the obtained results, it may be concluded that the research hypothesis was verified positively: investments in real estate may diversify a portfolio. This conclusion was drawn on the basis of the carried out analysis, bearing in mind, however, that direct real estate investments have their serious constraints. Although indirect investments are not as attractive, they should not be excluded by the investor due to their risk level, correlation with the capital market and rate of return. The authors even suggest a greater diversification of investment portfolios, with particular emphasis placed on indirect investments. Even though they do not present a record rate of return, the observation of risk measures allows one to suggest these investments as an interesting alternative to typical stock investments.

\section{Summary}

Investment possibilities on the real estate market depend on the level of market maturity. Economic, legal, cultural, social or political factors influence the range of investment opportunities - including the appearance of new solutions and their attractiveness to investors. Evaluation of the attractiveness of the Polish real estate market from the point of view of competition between many national markets informs us about the obstacles that make these investments difficult. They concern mainly the low diversity of the investment offer, which results not from the size of the market but from the lack of its transparency and lack of access to credible information. Furthermore, modest investment offers on the market of indirect investments in real estate, limited to close-end real estate investment funds and stocks of developer companies, along with the almost non-existent market of mortgage bonds, make the development of the real estate market very difficult, cutting off sources of financing. The presented analysis shows that there is still room for instruments of the real estate market in the portfolio, including more modern ones. However, the lack of data and transparency discourage investors and influence the low evaluation of attractiveness on the Polish real estate market in the ranking.

The authors would like to emphasize problems that limit the application of the research results as indicators for investors. The presented results concern a subjectively selected research period which influenced the results of the analysis. The period under consideration covered times of great turbulence on the financial markets. Also worth stressing is the fact that the results relating to developer companies' stock or to construction companies represented by the WIG-Budownictwo index are much closer to a typical capital market than a real estate one. These observations remain in accordance with observations made for markets that are more developed than the Polish real estate market. The authors considered close-end real estate investment funds to be the most interesting on the real estate market. Unfortunately, in Polish conditions, their legal form results in limiting their liquidity.

\section{Literature}

BOND S.A., HWANG S., RicHARDS K., 2006, Optimal Allocation to Real Estate Incorporating Illiquidity Risk, Journal of Asset Management, 7(1), 2-16.

BROWN G., MATYSIAK G., 2000, Real estate investment - a capital market approach, Prentice Hall.

BRUEGGEMAN W., FISHER J., 1997, Real estate finance and investments, Irwin, Chicago.

Clayton J., Gordon J., FAbOZZI F., Giliberto S.M., Liang Y., \& HudSON-WiLsON S., 2007, Real estate comes of age, Journal of Portfolio Management, 33, 15-26.

Corgel J. B., Smith H. C., LiAng D. C., 1998, Real Estate Perspectives: An Introduction to Real Estate, The McGraw-Hill Companies, Inc.

EICHHOLTZ P., 1997, Real estate securities and common stocks: a first international look, REF, 14 (4), 70-74.

FIORILla P., KAPAS M., LIANG Y., 2012, An institutional view of global real estate markets, Journal of Real Estate Portfolio, vol. 18 (1), 123-134.

Georgiev G., Gupta B., \& KunKel T., 2004, Benefits of Real Estate Investment, Journal Of Portfolio Management, 28-33.

HARTZELl D., HeKMAN J., \& Miles M., 1986, Diversification Categories in Investment Real Estate, AREUEA Journal, Journal Of The American Real Estate \& Urban Economics Association, 14 (2), 230-254.

HEANEY R., SRIANANTHAKUMAR S. 2012, Time-varying correlation between stock market returns and real estate returns. Journal Of Empirical Finance, 19(4), 583-594.

Lee S., Stevenson S., 2005, The Case for REITs in the Mixed-Asset Portfolio in the Short and Long Run, Journal of Real Estate Portfolio Management, 11, 55-80. 
LIESER K., GROH A.P., 2011, The Attractiveness of 66 Countries for Institutional Real Estate Investments: A Composite Index Approach, Journal of Real Estate Portfolio Management, vol. 17 (3), 191-211.

LiN Z., VANDELL K. D., 2007, Illiquidity and Pricing Biases in the Real Estate Market, Real Estate Economics, vol. 35, 291-330

PAi A., GELTNER D., 2007, Stocks are from Mars and real estate is from Venus, The Journal of Portfolio Management, vol. 33 (5), 134-144.

ZALECZNA M., 2010, Instytucjonalne uwarunkowania rozwoju rynku nieruchomości w Polsce na tle doświadczeń państw zachodnich, Wyd. UŁ, Łódź. 